
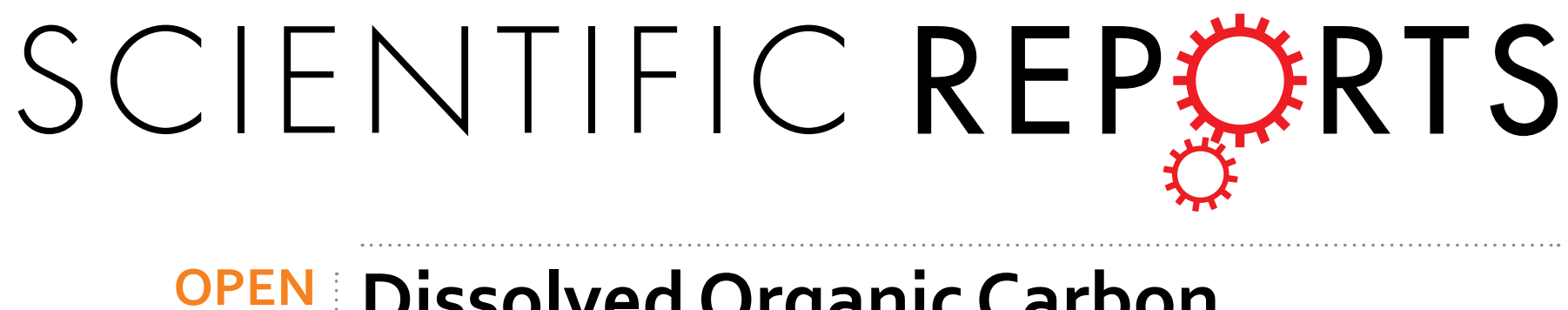

\title{
Dissolved Organic Carbon Mobilisation in a Groundwater System Stressed by Pumping
}

Received: 13 July 2015

Accepted: 19 November 2015

Published: 22 December 2015

\section{P. W. Graham, A. Baker \& M. S. Andersen}

The concentration and flux of organic carbon in aquifers is influenced by recharge and abstraction, and surface and subsurface processing. In this study groundwater was abstracted from a shallow fractured rock aquifer and dissolved organic carbon (DOC) was measured in observation bores at different distances from the abstraction bore. Groundwater abstraction at rates exceeding the aquifers yield resulted in increased DOC concentration up to 3,500 percent of initial concentrations. Potential sources of this increased DOC were determined using optical fluorescence and absorbance analysis. Groundwater fluorescent dissolved organic material (FDOM) were found to be a combination of terrestrial-derived humic material and microbial or protein sourced material. Relative molecular weight of FDOM within four metres of the abstraction well increased during the experiment, while the relative molecular weight of FDOM between four and ten metres from the abstraction well decreased. When the aquifer is not being pumped, DOC mobilisation in the aquifer is low. We hypothesise that the physical shear stress on aquifer materials caused by intense abstraction significantly increases the temporary release of DOC from sloughing of biofilms and release of otherwise bound colloidal and sedimentary organic carbon (SOC).

The concentration of DOC in groundwater is highly variable and sources and migration mechanisms are poorly understood. In soils and riverine systems, sorption and desorption of SOC from sediment and colloids, photo-degradation in the aquatic photic zone, and biodegradation are established factors that control OC biological and physiochemical processing ${ }^{1-4}$. Studies of riparian groundwater have described rivers as a major source of autochthonous and allochthonous DOC during periods of infiltration ${ }^{5-7}$. In addition subsurface flows that include groundwater interactions with the soil horizon, vegetation, or buried carbon lenses can cause significant variations in DOC distribution and concentrations in terrestrial waters ${ }^{8,9}$. Attenuation of DOC in soils is understood to be directly controlled by adsorption, co-precipitation and biodegradation. Groundwater redox state, $\mathrm{pH}$, nutrient availability, and water movement through the soil profile are thought to indirectly influence DOC attenuation ${ }^{10}$.

Research into the stabilisation and destabilisation of groundwater OM has focussed on the effects of: biofouling due to injection of nutrient rich water during bioremediation of contaminated soils or groundwater ${ }^{11-17}$; the creation of impermeable barriers around contaminated sites using enhanced biofilm growth ${ }^{18-20}$; the injection of water into oil reservoirs ${ }^{21}$; injection of $\mathrm{CO}_{2}$ rich brine on biofilm growth ${ }^{22}$. Typically these studies identify a significant accumulation of aerobic microbial populations in the immediate vicinity of the injection well, with increased concentrations of anaerobic microbial populations in areas further from the well screen ${ }^{17,21}$. Biofouling reduces the aquifer hydraulic conductivity, and therefore the majority of work undertaken focusses either on modelling the biofilm accumulation ${ }^{22-24}$, or replicating the systems in laboratory experiments to determine the most effective method for removal or reduction of the biofilm ${ }^{14,15}$. This existing literature is focussed on introduction of fluid to a porous medium (generally unconsolidated material or sandstone), which results in increased microbial growth either as an accidental or a planned occurrence. We are not aware of any research on OM accumulation and removal in fractured rock aquifers and none that considers the effects of intense groundwater extraction on native DOM.

Research into potential variations in DOC mobilisation during abstraction are limited to studies of the role of terrestrial organic carbon in mobilisation of arsenic in groundwater used for drinking supplies ${ }^{25,26}$. One possible mechanism of DOC release during abstraction is the erosion of biofilms and colloids or sloughing of biofilms from aquifer surfaces due to increased water velocity or shear stress. Research into the effect of water velocity and shear stress on colloid stability and biofilm erosion or sloughing has been limited to drinking water supply pipelines ${ }^{27,28}$ 


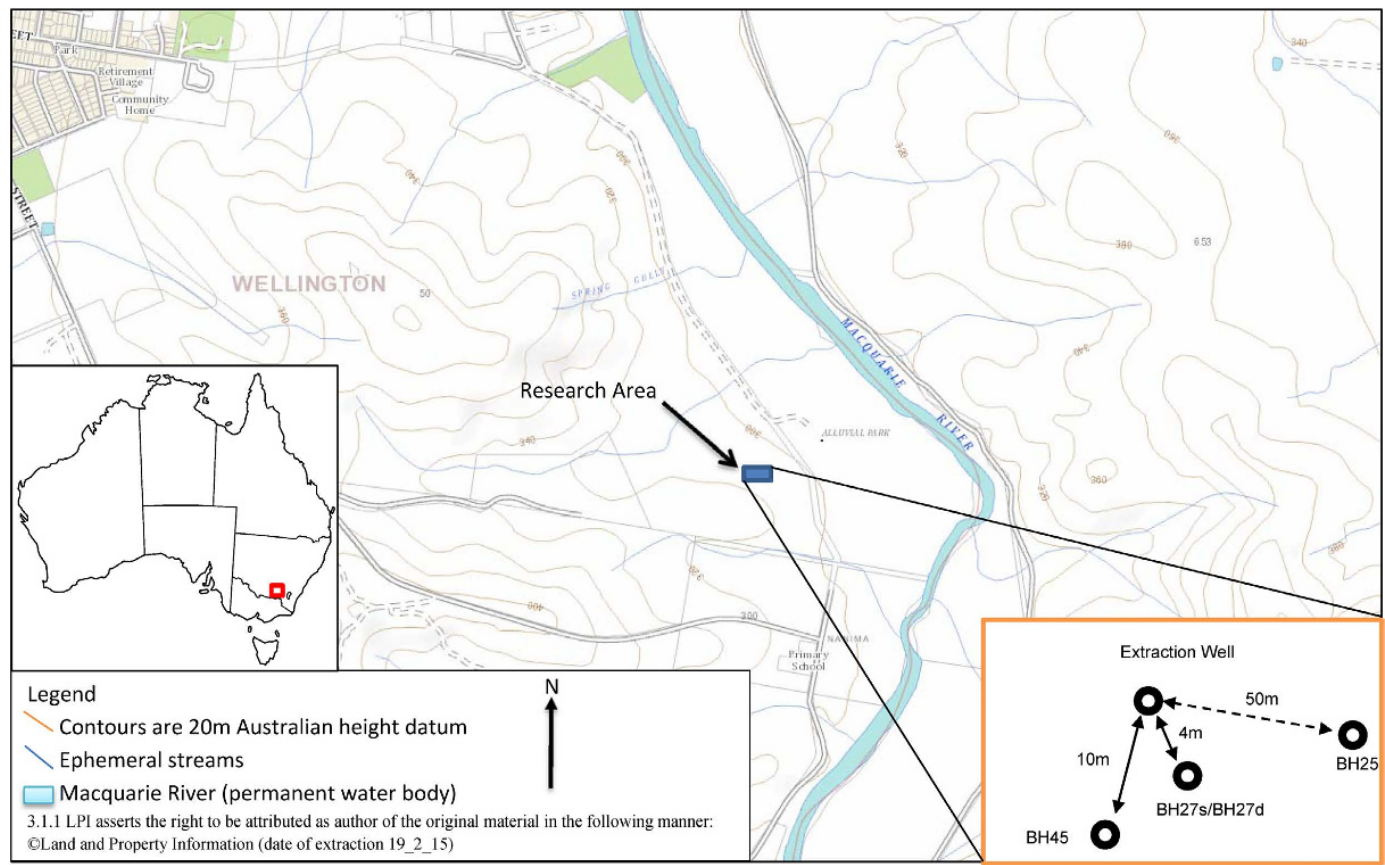

Figure 1. Site location, regional topography and relative bore locations (3.1.1 LPI asserts the right to be attributed as author of the original material in the following manner: @Land and Property Information (date of extraction 19/02/2015)).

and assessment of the effects on porosity and pore scale flow and diffusion caused by biofilm growth and sloughing in sedimentary or unconsolidated groundwater bioremediation systems ${ }^{12,13,29}$. Knutson, et al. ${ }^{29}$ found that shear strength were a significant mechanism controlling biomass development in a porous medium where water was injected for bioremediation purposes.

Shear detachment mechanisms for biofilms resulting from continuous substrate injection associated with bioremediation in porous media has been discussed in detail in MacDonald, et al. ${ }^{17}$. Detachment due to shear stress was found to reduce biomass by an order of magnitude and it was concluded that shear detachment played an important role in redistributing biomass within the aquifer ${ }^{17}$. Rittmann ${ }^{30}$ and Rittmann ${ }^{31}$ discuss the effects of shear stress on biofilm detachment within bioreactors using different reactor mediums such as fluidised sand and gravel beds. It was noted that biofilm loss rate due to shear stress was influenced by the composition of the porous medium with losses being higher on smooth surface sands relative to activated carbon. In this instance we are testing the effects of abstraction only within a fractured rock aquifer with no water or solute injection. We expect that shearing of biofilms would in this scenario play the major role in DOM mobilisation.

In this study we aim to identify changes in DOC characteristics and concentrations within a highly stressed aquifer. Groundwater levels and velocities were fluctuated by groundwater abstraction experiments at rates above the viable pumping rate. Through a combination of direct measurements of water, aquifer matrix and overburden $\mathrm{OC}$ we aim to determine whether bound organic carbon $(\mathrm{OC})$ is released as a result of the change in aquifer conditions. Quantification of DOC is undertaken by conventional laboratory methods ${ }^{32,33}$ and characterisation of DOC is undertaken through measurement of optical fluorescence and absorbance ${ }^{1,34,35}$. The experiments provide insights into changes in the concentration and character of groundwater DOC as a result of perturbations caused by groundwater pumping. The analysis of the variations in DOC within an aquifer during an abstraction experiment has not been undertaken before.

The experiment was undertaken at the UNSW Wellington Research Station in the central west of NSW, Australia (Fig. 1). See Graham, et al. ${ }^{36}$ for further information on the site. The research site is located on a gentle slope of less than five degrees with a Devonian fractured basalt/metasediment rock aquifer overlain by residual soils (between 0.5 and 9 metres thick) and flanked by a deep (up to 20 metres below ground level (mbgl)) Quaternary alluvial channel approximately 50 metres downgradient from the groundwater abstraction location. The fractured rock system outcrops in the upper reaches of the slope (approximately 100 metres south of the bore field) and becomes deeper down the slope to approximately $7 \mathrm{mbgl}$ at the abstraction location.

Based on observations made during drilling (December 2011 to February 2012) and head levels before and during abstraction the groundwater system in the vicinity of the bores is believed to consist of two fracture zones: a lower and upper fracture zone. Connectivity between these systems is moderate to low with both aquifers having similar piezometric heads under equilibrium conditions, however the upper system demonstrated a lagged response (e.g. drawdown) to abstraction from the lower system. The upper fracture system was overlain by weathered bedrock and saprolite. The upper system is therefore considered to be directly recharged by infiltrating rain water (Fig. 2). 


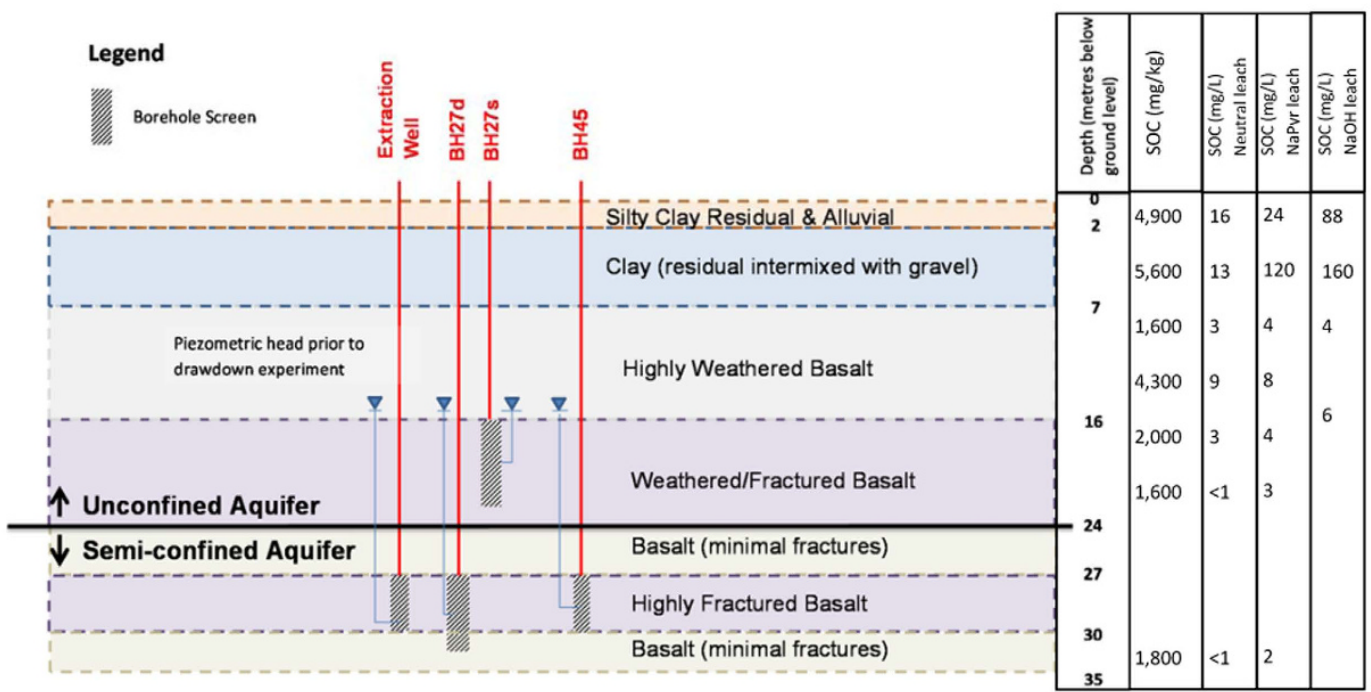

Figure 2. Schematic cross section of the investigation area.

\section{Results}

Figure 3 presents a summary of the experimental results including pumping rates, measured groundwater level and DOC concentration response for boreholes $\mathrm{BH} 27 \mathrm{~s}, \mathrm{BH} 27 \mathrm{~d}$ and $\mathrm{BH} 45$. Pumping rates varied between 12 and $30 \mathrm{~m}^{3} / \mathrm{hr}$ (Table 1 ). Approximately $410 \mathrm{~m}^{3}$ of water was abstracted over the five day experiment. The abstraction was sufficient to pump the aquifer in the immediate vicinity of the abstraction well dry once or twice a day. The abstraction was also observed to reduce groundwater levels $5 \mathrm{~m}$ distant from the abstraction bore by up to $7.5 \mathrm{~m}$ elevation.

Prior to, during, and following the experiment, chemical characteristics (temp, $\mathrm{pH}, \mathrm{EC}$ and DO) of the water were measured in the field. These have been summarised in Table 2.

Sedimentary Organic Carbon. The SOC content within the stratigraphic profile as measured from drilling samples is shown on Fig. 2 and Table 3. The results show that the amount of SOC leached into distilled water is generally low $(\sim 2 \mathrm{mg} / \mathrm{L})$ within the deeper $(>7 \mathrm{mbgl})$ sediments, however elevated concentrations (up to $160 \mathrm{mg} / \mathrm{L}$ ) were present within the soil profile, suggesting a potential DOC source which could be mobilised by infiltrating water. The location of this elevated SOC within the stratigraphic profile (4-5 mbgl) is vertically removed from the saturated zone of the groundwater system (approximately $16 \mathrm{mbgl}$ ) and apart from slow long term leaching with infiltration events this carbon is unlikely to be mobilised in the short term by the groundwater abstraction experiment (note there were no rainfall events during the abstraction experiment). In general the leachable fraction by any of the leaching methods is only a tiny percentage $(2.8 \%)$ of the total SOC in the profile.

Variation in Dissolved Organic Carbon due to Abstraction. An increase in DOC concentration was identified as a result of the high intensity pumping (i.e. abstraction rates which exceeded the aquifers yield). The highest DOC concentration the upper fracture zone $(72.75 \mathrm{mg} / \mathrm{L})$ was detected between one and seventeen hours after the abstraction well had been turned off and the aquifer left to recover. The highest DOC concentration in the lower fracture zone $(14.32 \mathrm{mg} / \mathrm{L})$ occurred between one and six hours after the initial abstraction commenced (Fig. 4).

The measured initial DOC concentrations in the upper aquifer (Borehole BH27s - Fig. 3) were approximately $2 \mathrm{mg} / \mathrm{L}$. Following abstraction these concentrations increased to an average (during the 5 day experiment) of $36 \mathrm{mg} / \mathrm{L}$ with a peak of $72.75 \mathrm{mg} / \mathrm{L}$. In the lower fracture zone (Boreholes BH27d and BH45 - Fig. 3) the initial DOC concentrations were approximately $1.6 \mathrm{mg} / \mathrm{L}$, during pumping these concentrations were found to increase to an average concentration (during the 5 day experiment) of $3.98 \mathrm{mg} / \mathrm{L}$ with a peak of $14.32 \mathrm{mg} / \mathrm{L}$.

Fluorescent Dissolved Organic Material. Analysis of the FDOM results using a PARAFAC model identified three consistent components in the data (detailed description of the PARAFAC Model is contained in the methods section of this manuscript). The three components were C1-320/400 Ex/Em (Excitation-Emission wavelengths) (terrestrial derived humic material), C2 - 250/470 Ex/Em (reprocessed, allochthonous humic materials) and C3 - 275/350 Ex/Em (microbial/protein type materials), corresponding to peaks $\mathrm{M} / \mathrm{C}, \mathrm{C}^{+}$and T respectively, as described by $\mathrm{Coble}^{34}$ and Ishii and Boyer ${ }^{37}$. Figure 4 shows the quantitative fluorescence intensity of each component in each borehole during the pumping experiment, Table 4 shows the fluorescence intensity of each component, absorbance (at $340 \mathrm{~nm}$ ) and DOC measured throughout the experiment.

The PARAFAC model results identified increases of up to 594, 624 and 361 percent of components C1, C2 and $\mathrm{C} 3$, during the pumping period in the upper aquifer. In the lower fracture zone increases of up to 232, 313 and 851 percent of components C1, C2 and C3 were identified. In this lower zone increases were generally observed immediately following a pumping event and generally returning to initial concentrations between one and sixteen hours after pumping was stopped (Fig. 4). In the lower fracture zone the presence of the C3 component was increased (average increase of 180 percent in borehole $\mathrm{BH} 27 \mathrm{~d}$ and $\mathrm{BH} 45$ ) with $\mathrm{C} 3$ being the dominant component 


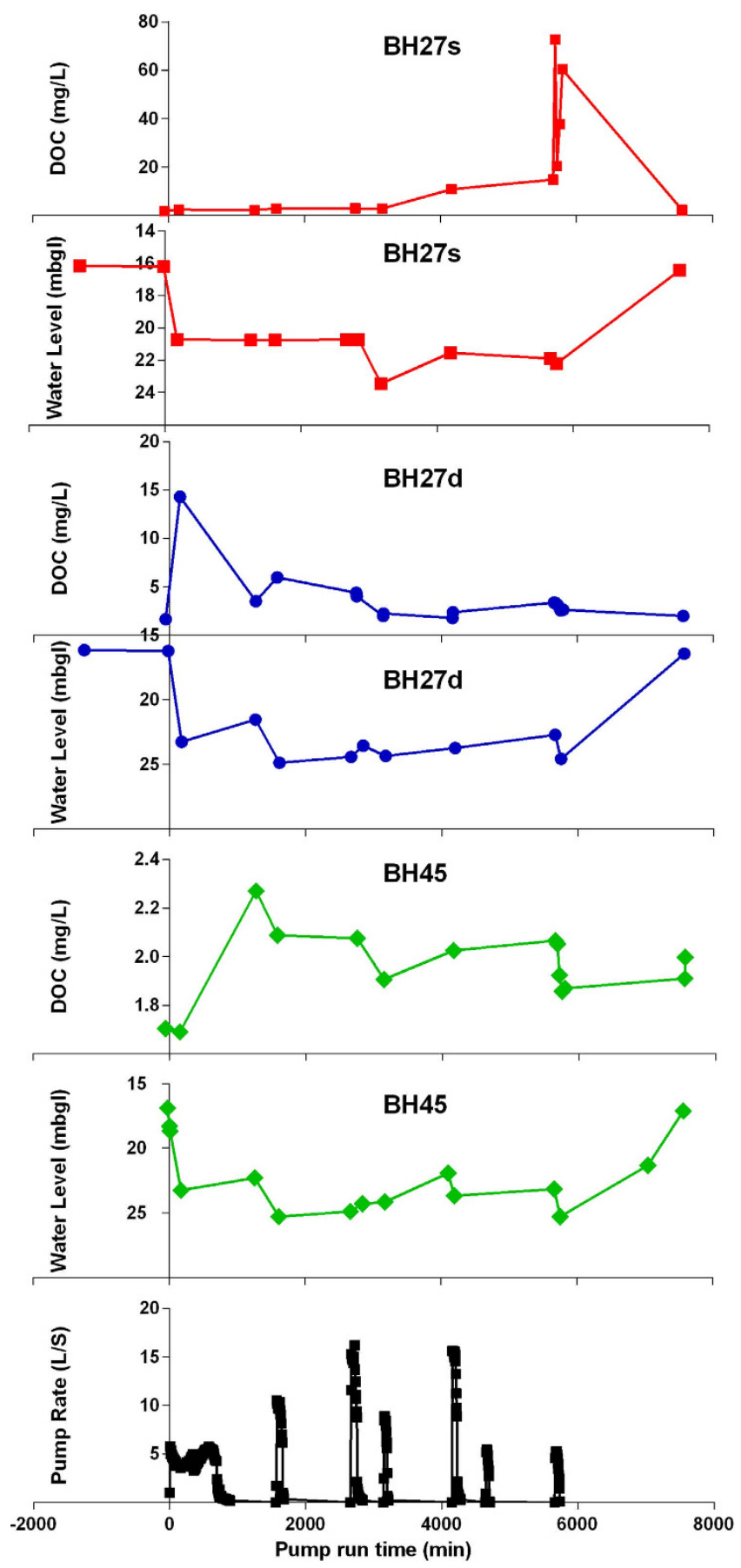

Figure 3. Pump rate and time series of groundwater levels and DOC.

in borehole BH27d (66, 42 and 87 average Quantitative Fluorescence Intensity (QFI) for components C1, C2 and $\mathrm{C} 3$ respectively) and being the secondary component (to $\mathrm{C} 1$ ) in $\mathrm{BH} 45$ (54, 33 and 46 average QFI for components $\mathrm{C} 1, \mathrm{C} 2$ and $\mathrm{C} 3$ respectively).

The correlation coefficients for Components C1, C2 and C3 to DOC in BH27s (Table 5) show a significant correlation between the $\mathrm{C} 1$ and $\mathrm{C} 2$ components and there is not a significant correlation to the $\mathrm{C} 3$ component, however in $\mathrm{BH} 27 \mathrm{~d}$ there is a significant correlation between $\mathrm{C} 2$ and $\mathrm{C} 3$. This suggests the FDOM in BH27s is more typical of primary, soil-derived humic material, while the FDOM in $\mathrm{BH} 27 \mathrm{~d}$ is more typical of microbial or bacterial derived material. The correlation coefficients for $\mathrm{BH} 45$ are not significant due to the low variability in DOC at that location.

DOM Absorbance and the Absorbance/Fluorescence Ratio. Stewart and Wetzel ${ }^{38}$ identified a relationship between the solubility of $\mathrm{OM}$ and the ratio of fluorescence intensity to absorbance, with a higher ratio indicating increased hydrophilicity (increased solubility). This relationship was further defined by Belzile and 


\begin{tabular}{|l|c|c|c|c|c|c|c|}
\hline \multirow{2}{*}{ Date } & \multicolumn{9}{|c|}{ Pump } & \multicolumn{2}{c|}{ Sample Time (UTC+ 10 hrs) } \\
\cline { 2 - 8 } & Start time & End time & rate $\left(\mathbf{m}^{3} / \mathbf{h r}\right)$ & Total Abstraction $\left(\mathbf{m}^{3}\right)$ & BH27s & BH27d & BH45 \\
\hline $21 / 03 / 2013$ & $\mathrm{n} / \mathrm{a}$ & $\mathrm{n} / \mathrm{a}$ & $\mathrm{n} / \mathrm{a}$ & $\mathrm{n} / \mathrm{a}$ & $14: 40$ & $15: 00$ & $15: 30$ \\
\hline $9 / 04 / 2013$ & $\mathrm{n} / \mathrm{a}$ & $\mathrm{n} / \mathrm{a}$ & $\mathrm{n} / \mathrm{a}$ & $\mathrm{n} / \mathrm{a}$ & $14: 22$ & $14: 49$ & $15: 11$ \\
\hline $18 / 04 / 2013$ & $12: 00$ & $03: 00^{*}$ & 12.91 & 193.75 & $11: 20$ & $11: 35$ & $11: 55$ \\
\hline $18 / 04 / 2013$ & - & - & - & - & $16: 00$ & $16: 22$ & $16: 40$ \\
\hline $19 / 04 / 2013$ & $14: 45$ & $16: 05$ & 24.45 & 32.60 & $09: 00$ & $09: 25$ & $09: 45$ \\
\hline $19 / 04 / 2013$ & - & - & - & - & $15: 00$ & $15: 25$ & $15: 55$ \\
\hline $20 / 04 / 2013$ & $08: 30$ & $11: 25$ & 25.45 & 71.31 & $08: 45$ & $09: 00$ & $09: 18$ \\
\hline $20 / 04 / 2013$ & $16: 30$ & $17: 30$ & 23.34 & 23.34 & $17: 05$ & $17: 20$ & $17: 35$ \\
\hline $21 / 04 / 2013$ & $09: 20$ & $11: 20$ & 30.81 & 61.63 & $08: 30$ & $08: 45$ & $09: 00$ \\
\hline $21 / 04 / 2013$ & $17: 30$ & $18: 25$ & 12.53 & 11.48 & $17: 35$ & $17: 50$ & $18: 12$ \\
\hline $22 / 04 / 2013$ & $10: 30$ & $11: 43$ & 16.24 & 19.76 & $10: 00$ & $10: 15$ & $10: 28$ \\
\hline $22 / 04 / 2013$ & - & - & - & - & $10: 45$ & $10: 55$ & $11: 10$ \\
\hline $22 / 04 / 2013$ & - & - & - & - & $11: 20$ & $11: 32$ & $11: 42$ \\
\hline $22 / 04 / 2013$ & $\mathrm{n} / \mathrm{a}$ & $\mathrm{n} / \mathrm{a}$ & $\mathrm{n} / \mathrm{a}$ & $\mathrm{n} / \mathrm{a}$ & $11: 48$ & $11: 55$ & $12: 10$ \\
\hline $22 / 04 / 2013$ & $\mathrm{n} / \mathrm{a}$ & $\mathrm{n} / \mathrm{a}$ & $\mathrm{n} / \mathrm{a}$ & $\mathrm{n} / \mathrm{a}$ & $12: 25$ & $12: 35$ & $12: 48$ \\
\hline $8 / 05 / 2013$ & $\mathrm{n} / \mathrm{a}$ & $\mathrm{n} / \mathrm{a}$ & $\mathrm{n} / \mathrm{a}$ & $\mathrm{n} / \mathrm{a}$ & $09: 03$ & $09: 25$ & $09: 55$ \\
\hline $15 / 05 / 2013$ & $\mathrm{n} / \mathrm{a}$ & $\mathrm{n} / \mathrm{a}$ & $\mathrm{n} / \mathrm{a}$ & $\mathrm{n} / \mathrm{a}$ & $14: 09$ & $14: 28$ & $14: 52$ \\
\hline $5 / 06 / 2013$ & $\mathrm{n} / \mathrm{a}$ & $\mathrm{n} / \mathrm{a}$ & $\mathrm{n} / \mathrm{a}$ & $\mathrm{n} / \mathrm{a}$ & $11: 23$ & $11: 48$ & $12: 06$ \\
\hline
\end{tabular}

Table 1. Pumping Rates and sampling events. n/a no pumping. UTC-Coordinated universal time. *abstraction ran until 3am on 19/04/2013. - indicates sampling within the same pumping period, for pump reading see rows above

\begin{tabular}{|l|c|c|c|c|c|}
\hline Borehole & Timing & Temp $\left({ }^{\circ} \mathbf{C}\right)$ & $\mathbf{p H}$ & $\mathbf{E C}(\boldsymbol{\mu s} / \mathbf{c m})$ & $\mathbf{D O}(\mathbf{m g} / \mathbf{L})$ \\
\hline BH27s & Before & 20.5 & 6.77 & 719 & 4.9 \\
\hline & During & 19.9 & 7.21 & 1,592 & $\mathrm{n} / \mathrm{a}$ \\
\hline & After & 19.6 & 7.11 & 859 & 5.5 \\
\hline BH27d & Before & 20.8 & 6.95 & 845 & 7.1 \\
\hline & During & 19.3 & 7.16 & 925 & $\mathrm{n} / \mathrm{a}$ \\
\hline & After & 19.3 & 7.01 & 865 & 10 \\
\hline BH45 & Before & 20.8 & 7.03 & 777 & 7.3 \\
\hline & During & 20.5 & 7.12 & 969 & $\mathrm{n} / \mathrm{a}$ \\
\hline & After & 19.2 & 7.08 & 861 & 9.5 \\
\hline
\end{tabular}

Table 2. Field Chemical Characteristics. Before = prior to commencement of abstraction (9/04/2013). During $=$ average of measurements taken during abstraction ( 11 measurements taken between 18/04/2013$22 / 04 / 2013)$. After $=$ measurement taken following abstraction $(08 / 05 / 2013)$. EC - Electrical Conductivity. DO - Dissolved Oxygen. n/a - DO probe was faulty for measurements made at these times

$\mathrm{Guo}^{39}$ through additional application of the method to OC adsorbed to colloidal matter. Organic material with higher molecular weight was shown to absorb light strongly at $250 \mathrm{~nm}$, but only fluoresced weakly, while OC of lower molecular weight fluoresced more intensely per unit absorbance. Baker, et al. ${ }^{40}$ demonstrated that peak $\mathrm{C}$ (excitation $300-350 \mathrm{~nm})$ : absorbance $(340 \mathrm{~nm})$ ratio had a high correlation $(0.86)$ to hydrophilicity of DOC.

Figure 5 shows the ratio of fluorescence intensity to absorbance for each of the borehole samples one month before, during, and one month after the experiment. The ratios before and after are similar in boreholes BH27d (pre abstraction- 25,514 to post abstraction 26,126 ) and $\mathrm{BH} 27 \mathrm{~s}$ (pre-abstraction 9,700 to post abstraction 11,285 ). An increase was noted in borehole BH45 (pre-abstraction 9,700 post abstraction 26,125). An increase (peak percentage increase of 657, 198 and 561 for Boreholes $\mathrm{BH} 27 \mathrm{~s}, \mathrm{BH} 27 \mathrm{~d}$ and $\mathrm{BH} 45$ respectively), but with significant variability, is observed during the abstraction events. The ratio measured in all boreholes increased during the experiment (maximum ratios of 63,750, 50,611 and 54,393 for Boreholes $\mathrm{BH} 27 \mathrm{~s}, \mathrm{BH} 27 \mathrm{~d}$ and BH45 respectively). The increased FDOM and chromophoric DOM (CDOM) being measured is more hydrophilic or has a lower molecular weight ${ }^{38}$. Reviewing the longer term effects of the experiment shows that the ratio at borehole BH45 increases throughout and following the experiment, suggesting that the character of FDOM/CDOM present in this location consistently changes to a more hydrophilic or lower molecular weight FDOM/CDOM type. The ratio in boreholes BH27s and $\mathrm{BH} 27 \mathrm{~d}$ are more stable. Borehole $\mathrm{BH} 27 \mathrm{~s}$ shows a general decreasing trend following the experiment, while borehole $\mathrm{BH} 27 \mathrm{~d}$ initially decreases however, it recovers to pre-experiment values within two months of the experiment. The decreasing ratios suggest increased hydrophobicity/higher molecular weight FDOM/CDOM character is present in these locations during that time. 


\begin{tabular}{|l|c|c|c|c|}
\hline & SOC $(\mathbf{m g} / \mathbf{k g})$ & \multicolumn{3}{|c|}{ Leachable SOC mg/L } \\
\hline Sample (mbgl) & & Distilled Water & Na Pyr & NaOH \\
\hline BH45 (0.0-1.0) & $\mathrm{n} / \mathrm{a}$ & 16 & 24 & 88 \\
\hline BH45 (2.0-3.0) & 4,900 & $<1$ & 11 & $\mathrm{n} / \mathrm{a}$ \\
\hline BH45 (3.0-4.0) & 5,600 & 7 & 16 & $\mathrm{n} / \mathrm{a}$ \\
\hline BH45 (4.0-5.0) & $\mathrm{n} / \mathrm{a}$ & 13 & 120 & 160 \\
\hline BH45 (8.0-9.0) & 1,600 & 3 & 4 & $\mathrm{n} / \mathrm{a}$ \\
\hline BH45 (9.0-10.0) & $\mathrm{n} / \mathrm{a}$ & 2 & 4 & 4 \\
\hline BH45 (12.0-13.0) & 4,300 & 9 & 8 & $\mathrm{n} / \mathrm{a}$ \\
\hline BH45 (13.0-14.0) & $\mathrm{n} / \mathrm{a}$ & 5 & 6 & 6 \\
\hline BH45 (15.0-16.0) & 2,000 & 3 & 4 & $\mathrm{n} / \mathrm{a}$ \\
\hline BH45 (22.0-23.0) & 1,600 & $<1$ & 3 & $\mathrm{n} / \mathrm{a}$ \\
\hline BH45 35.0-36.0) & 1,800 & $<1$ & 2 & $\mathrm{n} / \mathrm{a}$ \\
\hline BH27 (0.0-1.0) & $\mathrm{n} / \mathrm{a}$ & 7 & 36 & 43 \\
\hline BH27 (1.0-2.0) & 2,300 & 2 & 10 & $\mathrm{n} / \mathrm{a}$ \\
\hline BH27 4.0-5.0) & $\mathrm{n} / \mathrm{a}$ & 2 & 4 & 4 \\
\hline BH27 (7.0-8.0) & 4,300 & 1 & 3 & 3 \\
\hline BH27 (12.0-13.0) & $\mathrm{n} / \mathrm{a}$ & 1 & 3 & 2 \\
\hline BH27 (18.0-19.0) & 2,200 & 1 & 3 & $\mathrm{n} / \mathrm{a}$ \\
\hline BH27 (21.0-22.0) & 1,300 & $<1$ & 2 & $\mathrm{n} / \mathrm{a}$ \\
\hline BH27 (22.0-23.0) & 1,000 & $<1$ & 2 & $\mathrm{n} / \mathrm{a}$ \\
\hline
\end{tabular}

Table 3. Sedimentary OC analysis results. $\mathrm{Na} \mathrm{Pyr}-$ Sodium pyrophosphate. $\mathrm{NaOH}-$ Sodium Hydroxide. n/a - no analysis undertaken on this sample

\section{Discussion}

Here we have undertaken a study of the effects of high intensity abstraction of groundwater on OM mobilisation within a fractured rock aquifer. Previous studies in this research area have focussed on injection of water into aquifers and its effects on biofilm growth and the resultant variations in aquifer conductivity. We consider it likely that during periods of hydrological equilibrium the majority of organic carbon within the aquifer is adsorbed to solid surfaces as sedimentary organic carbon. During high intensity abstraction, high velocity groundwater flow sloughs and erodes biofilm from aquifer surfaces and increases the DOC concentration in the immediate vicinity (within 5 metres in this experiment) of the abstraction well.

Measurement of leachable SOC with de-ionised water, sodium hydroxide $(\mathrm{NaOH})$ and sodium pyrophosphate (NaPyr) leaching mediums demonstrated that significant amounts of leachable OC were not present in the overlying sediments and the largest component of SOC present was in a stable form. Based on the generally oxidised state of the groundwater at the site (Table 2) it is considered unlikely that lowering the groundwater level has resulted in significant oxidation and aerobic degradation of SOC causing increased leaching of DOC as previously observed by Moore and Dalva ${ }^{41}$. Therefore, although small amounts of leachable DOC may migrate through the soil profile with infiltrating rain water, this component seems relatively minor, which is supported by the study of Borisover, et al. ${ }^{42}$.

The physical effect of water velocity on biofilm detachment is broadly categorized into two processes: erosion of small particles from the surface of the biofilm and sloughing of large pieces (detachment from the inner area or base of the biofilm). The effects of variations in shear stress on biofilm detachment within drinking water pipelines and porous media has previously been studied ${ }^{11,17,27-29,43-46}$. However, to our knowledge it has not yet been studied in fractured rock aquifers. Hence, to gain insights here, we reference the findings of shear stress promoted biofilm detachment in pipe systems and unconsolidated porous sediments. We consider pipe systems more closely replicate likely flow patterns in a fractured rock aquifer than studies in unconsolidated porous sediments. Choi and Morgenroth ${ }^{28}$ found that constant shear stress resulted in erosion type detachment, while a sudden increase in shear stress caused significant increases in both the concentration and particle size of the detached biofilm. Cloete, et al. ${ }^{27}$ analysed the response of biofilm detachment to fluid velocity variations within pipe systems. Their study identified biofilm detaching at velocities of above 3 to 4 metres per second. These detaching velocities were sufficient to result in ongoing erosion of the biofilm preventing further build-up of biofilm layers. Lower velocities were found to be capable of detaching biofilms, but were not sufficient to prevent ongoing build up. Wang, et al. ${ }^{43}$ noted that biofilms grown in low velocity regimes were more likely to detach and measured detachment rates of between 40 and 60 percent during flows ranging between 0.04 and 0.28 metres per second. A value of $0.005 \mathrm{~N} / \mathrm{m}^{2}$ was suggested to best represent the critical shear stress, at which biofilm is detached in an average porous medium for various microbial species ${ }^{12,29}$.

The velocity of water flowing through a fractured rock aquifer is potentially highly variable and dependent on flow events (i.e. abstraction) and on the connectivity of the fracture system. It is a common assumption when assessing fractured rock aquifers to ignore the matrix flow and focus only on flow within the fractures ${ }^{47}$. Approximate calculations of possible flow velocities within fractures in the immediate vicinity of the abstraction bore have been made based on the peak abstraction rate of $30.81 \mathrm{~m}^{3} / \mathrm{hr}$. The surface area of flow at the abstraction well aquifer boundary would be $2.2 \mathrm{~m}^{2}$ (based on a screen radius of $0.12 \mathrm{~m}$ and screen length of $3 \mathrm{~m}$ ). Flow across this surface area would be delivered by the permeable fractures which based on field observations (made during installation of 

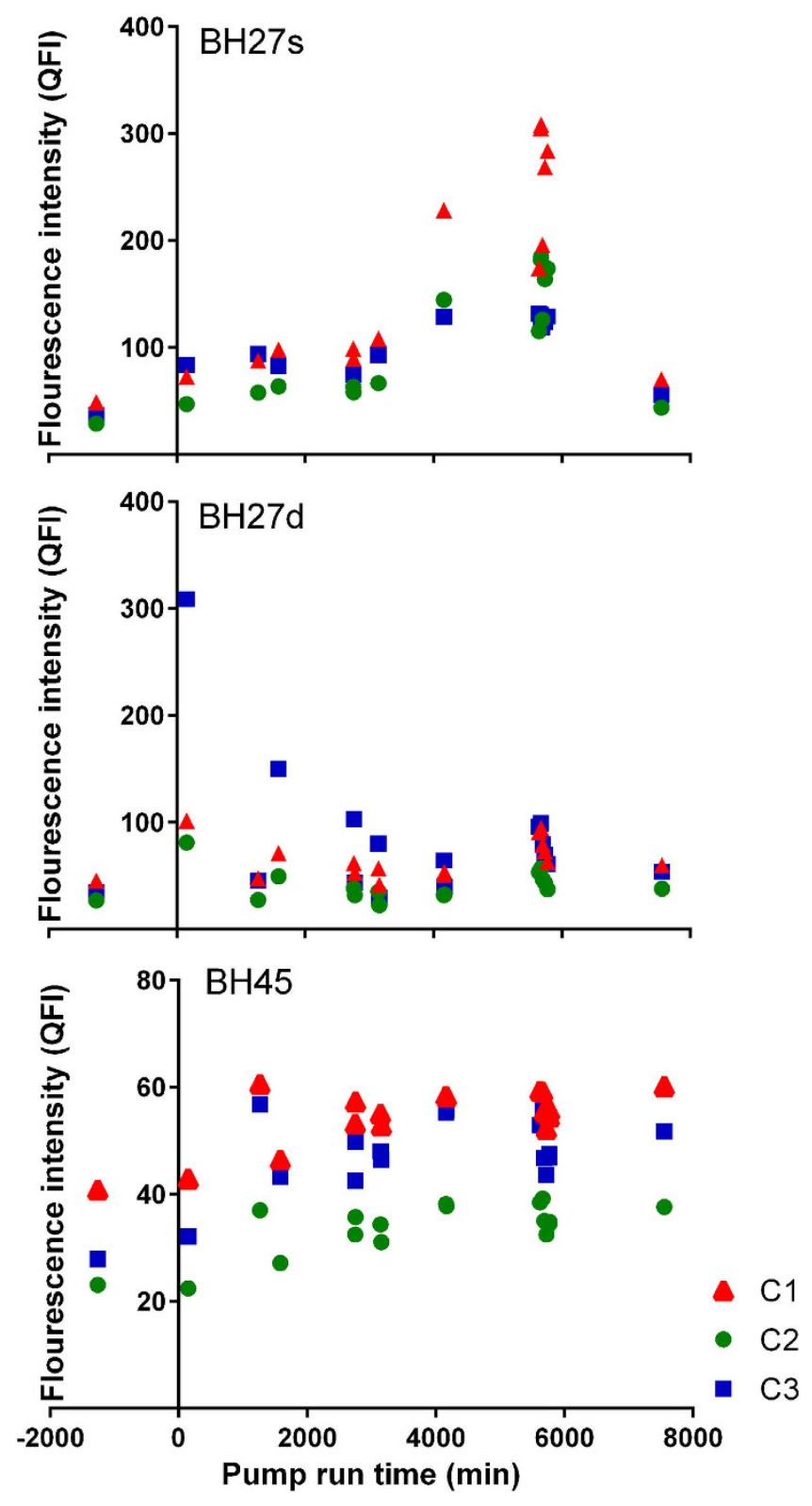

Figure 4. Time series of PARAFAC fluorescence components.

the abstraction bore) and review of core material collected from an adjacent borehole (see supplementary material) make up between 0.1 and 5 percent of the aquifer matrix, the actual surface area of flow would therefore then be reduced to between 0.0022 and $0.11 \mathrm{~m}^{2}$. Using the principle of continuity of flow ${ }^{48}$ :

$$
\mathrm{Q}=\mathrm{v} * \mathrm{~A}
$$

(where $\mathrm{Q}=$ flow in $\mathrm{m}^{3} / \mathrm{s}, \mathrm{v}=$ velocity in $\mathrm{m} / \mathrm{s}$ and $\mathrm{A}=$ area in $\mathrm{m}^{2}$ ), the velocity expected within the fractures would be between 0.38 and $0.08 \mathrm{~m} / \mathrm{s}$. However, it is reasonable to assume that at times during the peak abstraction rates flow would be limited to only a few fractures representing less than one percent of the total rock mass. In this instance the flow velocity in these fractures are likely to exceed $0.4 \mathrm{~m} / \mathrm{s}$. This flow rate could be even higher during short pulses due to non-linear responses within the fracture matrix as the pump is switched on or off.

Novakowski ${ }^{49}$ suggested that in most natural systems a few fractures deliver a majority of the flow resulting in very high velocities within these fractures. This results in a zone of non-Darcian flow in the aquifer near the well and non-linear responses to pumping which are considered to be a result of a large transition zone between linear and turbulent flow. This transition zone is caused by fracture geometry characteristics including fracture roughness, dead end voids, aperture variations and contact area ${ }^{49}$. The water velocity is expected to decrease with distance from the extraction bore due to a radial increase in fracture density. This increase is dependent on fracture connectivity and other factors as described by Novakowski ${ }^{49}$. At a distance of four metres from the extraction bore (borehole BH27d) the fracture flow area is expected to increase from $0.075 \mathrm{~m}^{2}$ to $0.38 \mathrm{~m}^{2}$, resulting in flows of between $0.11 \mathrm{~m} / \mathrm{s}$ to $0.02 \mathrm{~m} / \mathrm{s}$. These flow rates are considered sufficient to result in the observed biofilm detachment 


\begin{tabular}{|c|c|c|c|c|c|c|c|c|c|c|c|c|c|c|c|}
\hline \multirow[b]{2}{*}{ Date } & \multicolumn{5}{|c|}{ BH27s } & \multicolumn{5}{|c|}{ BH27d } & \multicolumn{5}{|c|}{ BH45 } \\
\hline & $\begin{array}{c}\mathrm{C1} \\
\text { (QFI) }\end{array}$ & $\begin{array}{c}\mathrm{C} 2 \\
\text { (QFI) }\end{array}$ & $\begin{array}{c}\text { C3 } \\
\text { (QFI) }\end{array}$ & $\underset{(-\log T)}{\alpha \text { OD }}$ & $\begin{array}{c}\text { DOC } \\
(\mathrm{mg} / \mathrm{L})\end{array}$ & $\begin{array}{c}\text { C1 } \\
(\mathrm{QFI})\end{array}$ & $\begin{array}{c}\text { C2 } \\
(\mathrm{QFI})\end{array}$ & $\begin{array}{c}\text { C3 } \\
(\mathrm{QFI})\end{array}$ & $\underset{(-\log T)}{\alpha \text { OD }}$ & $\begin{array}{c}\text { DOC } \\
(\mathrm{mg} / \mathrm{L})\end{array}$ & $\begin{array}{c}\text { C1 } \\
(\mathrm{QFI})\end{array}$ & $\begin{array}{c}\mathrm{C} 2 \\
(\mathrm{QFI})\end{array}$ & $\begin{array}{c}\text { C3 } \\
\text { (QFI) }\end{array}$ & $\underset{(-\log T)}{\alpha \text { OD }}$ & $\begin{array}{c}\text { DOC } \\
(\mathrm{mg} / \mathrm{L})\end{array}$ \\
\hline $21 / 03 / 13$ & 54 & 32 & 40 & 0.0087 & $\mathrm{n} / \mathrm{a}$ & 44 & 26 & 36 & $\mathrm{n} / \mathrm{a}$ & $\mathrm{n} / \mathrm{a}$ & 45 & 28 & 38 & 0.0093 & $\mathrm{n} / \mathrm{a}$ \\
\hline $9 / 04 / 13$ & 51 & 29 & 36 & 0.0055 & $\mathrm{n} / \mathrm{a}$ & 48 & 29 & 45 & 0.0072 & $\mathrm{n} / \mathrm{a}$ & 43 & 25 & 30 & $\mathrm{n} / \mathrm{a}$ & $\mathrm{n} / \mathrm{a}$ \\
\hline 18/04/13 (am) & 73 & 47 & 84 & 0.0032 & 1.90 & 46 & 27 & 34 & 0.0098 & 1.67 & 41 & 23 & 28 & 0.0065 & 1.70 \\
\hline $18 / 04 / 13(\mathrm{pm})$ & $\mathrm{n} / \mathrm{a}$ & $\mathrm{n} / \mathrm{a}$ & $\mathrm{n} / \mathrm{a}$ & $\mathrm{n} / \mathrm{a}$ & 2.49 & 102 & 81 & 309 & 0.017 & 14.32 & 43 & 22 & 32 & $\mathrm{n} / \mathrm{a}$ & 1.69 \\
\hline 19/04/13 (am) & 88 & 58 & 94 & 0.0077 & 2.29 & 47 & 27 & 46 & 0.0085 & 3.53 & 61 & 37 & 57 & 0.0084 & 2.27 \\
\hline 19/04/13 (pm) & 98 & 64 & 83 & 0.0099 & 2.94 & 71 & 49 & 150 & 0.0086 & 5.98 & 46 & 27 & 43 & $\mathrm{n} / \mathrm{a}$ & 2.09 \\
\hline 20/04/13 (am) & 99 & 63 & 74 & 0.0069 & 3.01 & 62 & 38 & 103 & 0.0044 & 4.40 & 53 & 32 & 43 & 0.0081 & 2.08 \\
\hline 20/04/13 (pm) & 108 & 66 & 93 & 0.0068 & 2.90 & 57 & 35 & 80 & 0.0034 & 2.00 & 53 & 31 & 46 & 0.0045 & 2.03 \\
\hline 21/04/13 (am) & 228 & 145 & 129 & 0.0172 & 10.88 & 51 & 32 & 64 & 0.0038 & 1.79 & 58 & 38 & 55 & 0.0048 & $\mathrm{n} / \mathrm{a}$ \\
\hline 21/04/13 (pm) & $\mathrm{n} / \mathrm{a}$ & $\mathrm{n} / \mathrm{a}$ & $\mathrm{n} / \mathrm{a}$ & $\mathrm{n} / \mathrm{a}$ & $\mathrm{n} / \mathrm{a}$ & 54 & 32 & 40 & $\mathrm{n} / \mathrm{a}$ & 2.38 & $\mathrm{n} / \mathrm{a}$ & $\mathrm{n} / \mathrm{a}$ & $\mathrm{n} / \mathrm{a}$ & $\mathrm{n} / \mathrm{a}$ & $\mathrm{n} / \mathrm{a}$ \\
\hline $22 / 04 / 13$ & 174 & 115 & 132 & $\mathrm{n} / \mathrm{a}$ & 14.91 & 91 & 54 & 96 & 0.0082 & 3.37 & 59 & 38 & 53 & 0.0038 & 2.07 \\
\hline $22 / 04 / 13$ & 305 & 182 & 128 & 0.0302 & 72.75 & 95 & 57 & 99 & 0.0097 & 3.32 & 59 & 39 & 56 & 0.0028 & 2.05 \\
\hline $22 / 04 / 13$ & 196 & 126 & 119 & 0.0147 & 20.50 & 79 & 47 & 79 & 0.0088 & 3.11 & 56 & 35 & 47 & 0.0025 & 1.92 \\
\hline $22 / 04 / 13$ & 269 & 164 & 124 & 0.0255 & 60.63 & 73 & 43 & 69 & 0.0095 & 2.63 & 52 & 32 & 44 & 0.0027 & 1.87 \\
\hline $22 / 04 / 13$ & 284 & 174 & 129 & 0.0274 & 37.64 & 63 & 37 & 61 & $\mathrm{n} / \mathrm{a}$ & 2.58 & 54 & 34 & 47 & 0.0025 & 1.86 \\
\hline $8 / 05 / 13$ & 84 & 50 & 63 & $\mathrm{n} / \mathrm{a}$ & 2.44 & 64 & 43 & 60 & $\mathrm{n} / \mathrm{a}$ & $\mathrm{n} / \mathrm{a}$ & 65 & 43 & 59 & $\mathrm{n} / \mathrm{a}$ & 1.91 \\
\hline $15 / 05 / 13$ & 70 & 44 & 55 & 0.0167 & 2.02 & 60 & 38 & 54 & $\mathrm{n} / \mathrm{a}$ & 2.01 & 60 & 38 & 52 & 0.0069 & 2.00 \\
\hline $5 / 06 / 13$ & $\mathrm{n} / \mathrm{a}$ & $\mathrm{n} / \mathrm{a}$ & $\mathrm{n} / \mathrm{a}$ & 0.0237 & $\mathrm{n} / \mathrm{a}$ & $\mathrm{n} / \mathrm{a}$ & $\mathrm{n} / \mathrm{a}$ & $\mathrm{n} / \mathrm{a}$ & 0.0066 & 1.91 & $\mathrm{n} / \mathrm{a}$ & $\mathrm{n} / \mathrm{a}$ & $\mathrm{n} / \mathrm{a}$ & 0.0065 & 1.87 \\
\hline
\end{tabular}

Table 4. PARAFAC, absorbance and DOC analysis results. $n / a$ - results not available for this sample. QFI quantitative fluorescence intensity. $\alpha \mathrm{OD}-\mathrm{UV}$ absorbance at $340 \mathrm{~nm}$

\begin{tabular}{|c|c|c|c|c|}
\hline Correlation Coefficient $^{1}$ & $\mathrm{BH} 27 \mathrm{~s}$ & BH27d & BH45 & Site $\mathrm{Ave}^{2}$ \\
\hline C1 vs Abs $(340 \mathrm{~nm})$ & 0.82 & 0.04 & 0.07 & 0.73 \\
\hline C2 vs Abs $(340 \mathrm{~nm})$ & 0.80 & 0.04 & 0.12 & 0.69 \\
\hline C3 vs Abs $(340 \mathrm{~nm})$ & 0.47 & 0.04 & 0.06 & 0.37 \\
\hline C1 vs DOC $(\mathrm{mg} / \mathrm{L})$ & 0.79 & 0.38 & 0.34 & 0.86 \\
\hline C2 vs DOC $(\mathrm{mg} / \mathrm{L})$ & 0.75 & 0.69 & 0.27 & 0.84 \\
\hline C3 vs DOC $(\mathrm{mg} / \mathrm{L})$ & 0.44 & 0.94 & 0.47 & 0.28 \\
\hline $\begin{array}{l}\text { Abs }(340 \mathrm{~nm}) \text { vs DOC } \\
(\mathrm{mg} / \mathrm{L})\end{array}$ & 0.78 & 0.57 & 0.11 & 0.56 \\
\hline
\end{tabular}

Table 5. Correlation Coefficients. ${ }^{1}$ Correlation coefficient calculated using the Pearson product-moment correlation coefficient method. ${ }^{2}$ Site Ave-average of boreholes BH27s, BH27d and BH45, $(\mathrm{n}=12) .{ }^{3}$ bold values are statistically significant.

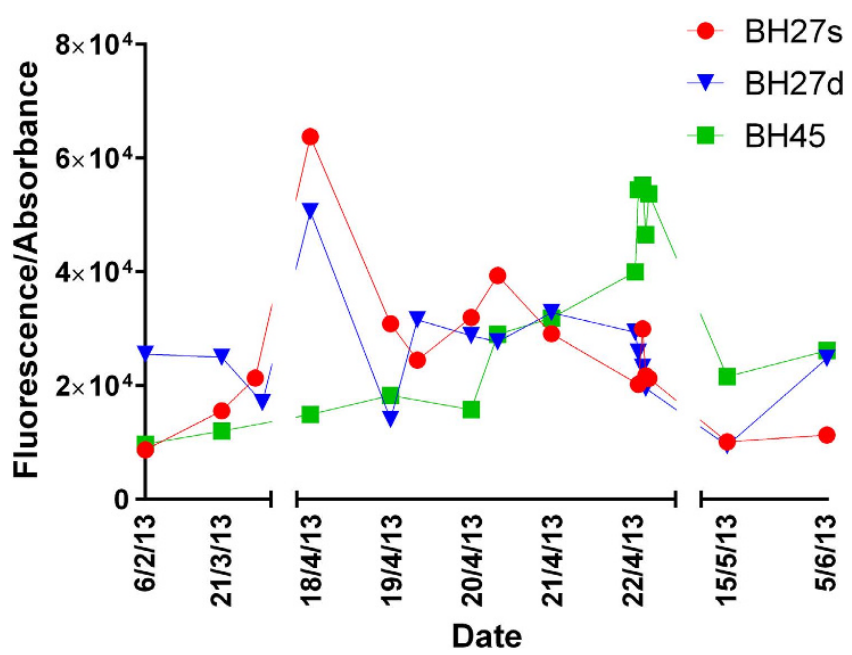

Figure 5. Ratio of total fluorescence to absorbance $(340 \mathrm{~nm})$ in boreholes prior to, during and after pumping. 
at borehole $\mathrm{BH} 27 \mathrm{~d}$. Inspection of the core materials from the fractured rock aquifer suggest that fracture surfaces at the subject site were smooth and would therefore be expected to facilitate significant biofilm loss due to shear stress.

The estimated shear velocity at the subject site was considered during abstraction to be within the range of 0.40 to $0.08 \mathrm{~m} / \mathrm{s}$, if the water density is assumed to be $1 \mathrm{~g} / \mathrm{cm}^{3}$ then the shear stress can be expressed as 0.4 to $0.08 \mathrm{~N} / \mathrm{m}^{2}$. This is well within the range of $0.005 \mathrm{~N} / \mathrm{m}^{2}$ suggested by Tang, et al. ${ }^{12}$ and Knutson, et al. ${ }^{29}$. As outlined above, the shear stress required to detach biofilm within water pipes, are generally a magnitude higher than those required for detachment in porous mediums and would be considered more relevant to what may be expected in a fractured rock scenario. In either case the study has shown that shear velocity resulting from the high intensity abstraction could be expected to exceed the required biofilm detachment shear velocity.

Further complicating the potential for SOC to mobilise during abstraction is the concept of fracture skins, described as a thin coating on the rock matrix with different sorption and diffusion properties to that of the undisturbed rock matrix. The skin includes zones of altered rock and coatings of the rock surface by organic matter, precipitated minerals and infiltrated debris ${ }^{50}$ and their influence as a potential source of DOC ${ }^{51}$.

van Beek, et al. ${ }^{52}$ compared variations in sediment particle volume and size distribution in groundwater abstracted at varying rates. Their experiment found that higher discharge rates corresponded to increased particle volume and particle size (from 2 to $10 \mu \mathrm{m}$ ). It was also noted that the concentration of particles was higher in younger wells suggesting that ongoing abstraction will eventually exhaust the accessible particle supply around the abstraction well. The van Beek et al. ${ }^{31}$ experiment was undertaken within an alluvial aquifer and therefore differs in geological setting (and hence flow patterns) from our experiment, however a similar phenomenon is expected to occur within a fractured system.

Considering the rate of abstraction achieved during the experiment (up to 0.28 metres per second), the resulting shear stress and water velocity would be sufficient to result in sloughing of biofilms with potential to include both particulate SOC and $\mathrm{DOC}^{43}$ from the fracture surfaces. This is demonstrated by elevated concentrations of DOC in borehole $\mathrm{BH} 27 \mathrm{~d}$ at the start of the abstraction, which were identified as FDOM with an elevated ratio of PARAFAC model Component 3 to Components 1 and 2. Component 3 is representative of the microbial/protein type DOM which are expected to be the primary type of DOC released from biofilms ${ }^{43}$. During the experiment it was noted that the DOC increase in $\mathrm{BH} 27 \mathrm{~d}$ was higher than that measured in $\mathrm{BH} 45$ and that the DOC identified in $\mathrm{BH} 45$ was typically of lower molecular weight. This is expected to be due to the proximity of piezometer $\mathrm{BH} 27 \mathrm{~d}$ to the abstraction point and exposure of fractures close to the extraction well to higher water velocities and thus higher shear stresses.

Stewart and Wetzel ${ }^{38}$ and Belzile and $\mathrm{Guo}^{39}$ identified a relationship between the molecular weight of dissolved humic material and the fluorescence to absorbance ratio. These correlations were utilised to establish any variations in the relative molecular weight of the DOC identified (Table 4, Fig. 5). The DOC observed in BH45 was noted to have a relatively low molecular weight and is likely to be composed of relatively hydrophilic OC. We hypothesise that this is more mobile and is carried by groundwater being drawn in from other areas of the aquifer. The measured long term trend suggested that the relative molecular weight of DOC within borehole BH45 continued to decrease after the abstraction experiment ended. This suggests that the experiment had acted to mobilise relatively higher molecular weight $\mathrm{OC}$ in the immediate vicinity of the abstraction well (borehole $\mathrm{BH} 27 \mathrm{~d}$ ) by the velocity shearing action. As for the increase in the relatively lower molecular weight fraction it is possible that by lowering the water table we are sampling more recently recharged waters from across the shallower part of the general aquifer.

The elevated concentrations of DOC identified during the abstraction experiment in borehole $\mathrm{BH} 27 \mathrm{~s}$ was mainly due to increase in the $\mathrm{C} 1$ to $\mathrm{C} 2$ components, which are indicative of locally derived humic and reprocessed humic materials. Borehole $\mathrm{BH} 27 \mathrm{~s}$ is screened across the upper fracture zone which is likely to receive direct recharging waters which have percolated through the overlying soil/saprolite profile.

This experiment has found that available DOC in a groundwater system in a normal state (not exposed to anthropogenic abstraction) would generally be within the range of $1-2 \mathrm{mg} / \mathrm{L}$. We assume this is due to OC entering the system being adsorbed, taken up by microbes or microbially processed (mineralised). However, increased groundwater velocities in fractures during abstraction resulted in larger shear stresses within the aquifer. These two factors are considered to have contributed to increased DOC mobilisation of up to $72 \mathrm{mg} / \mathrm{L}$ within the aquifer.

Assessment of SOC within the geological profile has not identified a significant source of OC within the vadose or unsaturated zones as the SOC in these locations is in a stable (non-leachable) state. We consider it likely that, greatly increasing the water velocity and hence the shear stress in the immediate vicinity of the abstraction bore would result in the shearing of biofilms from aquifer surfaces or fracture skins ${ }^{27,28}$. This plausible explanation is supported by the observed increase in relatively high molecular weight OC due to the pumping, which in the absence of leachable OC higher in the profile must result from biofilm detachment.

In our study the effect was observed within bores four metres from the extraction well but not at 10 metres, however more generally this distance would in other settings be dependent on the fracture density and abstraction rates. While van Beek, et al. ${ }^{52}$ have demonstrated that the colloid supply may be exhausted over time, there would be ongoing accumulation of biofilms on surfaces within the aquifer as observed in water supply pipes in Cloete, et al. ${ }^{27}$. This process would continue to concentrate $\mathrm{OC}$ from the groundwater in a form that can be reintroduced into the terrestrial cycle through groundwater abstraction.

Future research could assess whether the release of DOC during abstraction is limited to the areas immediately surrounding the abstraction well or if DOC further from the abstraction well would also be released as the abstraction continues as this would determine the potential quantity of carbon released during abstraction. We have also suggested that one of the main sources of OC (biofilms) could replenish and therefore could act as an ongoing source of DOC within the groundwater. Assessment of the potential for the biofilms to replenish requires confirmation. A long term study of the steady state OC flux during abstraction would therefore be a useful study for comparison. Finally, the sloughing of biofilms was identified as a likely source of DOC. Of interest would be 
future studies incorporating both particulate and dissolved organic carbon analysis from samples of groundwater collected during varying stages of abstraction.

\section{Methods}

Abstraction was undertaken from an abstraction well (EW02) cased in $240 \mathrm{~mm}$ polyvinyl chloride (PVC) and a four metre screen was placed across a two to three metre fracture zone located at a depth of approximately 28 to $30 \mathrm{mbgl}$. Monitoring was undertaken in borehole $\mathrm{BH} 27$, a nested well located approximately four metres to the south of the abstraction well and BH45 located approximately 10 metres south west of the abstraction well. The shallow piezometer in $\mathrm{BH} 27$ (BH27s) was constructed of $50 \mathrm{~mm}$ PVC with a machine slotted screen between 20 and $23.5 \mathrm{mbgl}$, intercepting a minor fracture zone within weathered bedrock. The deep piezometer in $\mathrm{BH} 27$ (BH27d) was also constructed of $50 \mathrm{~mm}$ PVC with a machine slotted screen between 27.5 and $33 \mathrm{mbgl}$, intercepting the same deeper fracture zone as EW02. A one metre thick bentonite plug was placed in the BH27 borehole between 25 and $26 \mathrm{mbgl}$ to isolate the two piezometers. Borehole $\mathrm{BH} 45$ was cased with steel to $3.5 \mathrm{mbgl}$ but uncased to a depth of $30 \mathrm{mbgl}$. During drilling of $\mathrm{BH} 45$ the upper fracture zone identified in $\mathrm{BH} 27$ was not encountered, however a deeper fracture zone was encountered at a depth of approximately 26 to $27 \mathrm{mbgl}$.

As part of a separate project a borehole (borehole BH25) was drilled approximately 50 metres to the east of borehole $\mathrm{BH} 27$. Borehole $\mathrm{BH} 25$ was diamond cored through the same geological materials as boreholes $\mathrm{BH} 27$ and $\mathrm{BH} 45$. The core samples were inspected to determine the representative fracture distribution and size. Photos of this core material have been included in the supplementary material.

During drilling of boreholes $\mathrm{BH} 27, \mathrm{BH} 45$ and extraction well EW02 it was noted that the bedrock between $23.5 \mathrm{mbgl}$ and $27 \mathrm{mbgl}$ increased in competency and was dry, suggesting connectivity between the two fracture zones would be limited to fracture flow. Prior to abstraction groundwater levels in in all boreholes were generally 16.10 to $16.20 \mathrm{mbgl}$. During abstraction an immediate drawdown response was noted in boreholes $\mathrm{BH} 27 \mathrm{~d}$ and $\mathrm{BH} 45$, however the response in $\mathrm{BH} 27 \mathrm{~s}$ lagged by approximately an hour suggesting that the upper and lower fracture systems are connected, but with limited connectivity.

Throughout the experiment the groundwater abstraction rates were monitored with a V-notch weir and groundwater levels were recorded every $10 \mathrm{~min}$ using submersible pressure transducers. Pumping rates and sampling times are shown in Table 1. Abstraction was undertaken at a rate which exceeded the yield of the well and EW02 was pumped dry one to two times a day for five days (18 April to 22 April 2013 - Table 1). This cyclic operation of the pump allowed for an aggressive abstraction schedule that promoted variations in water velocity and shear stress in the aquifer to allow potential biofilm detachment to be incorporated into the measured DOC mass.

Groundwater samples were collected monitoring wells within the lower fracture system (Boreholes BH27d and $\mathrm{BH} 45)$ and upper fracture system (BH27d) using a centrifugal pump one month, a week and a day prior to the experiment and then during the experiment approximately one hour after abstraction had commenced (Table 1 details the sampling times). The sampling pump intake point was positioned at the approximate depth of the main fracture zones as identified during piezometer installations, these were $29 \mathrm{mbgl}$ for $\mathrm{BH} 27 \mathrm{~d}, 20 \mathrm{mbgl}$ for $\mathrm{BH} 27 \mathrm{~s}$ and $28.5 \mathrm{mbgl}$ for BH45.

Samples were then collected one day, one week and one month following the experiment. Prior to sampling all locations were dipped to measure the standing water level. Groundwater was pumped through a flow cell measuring $\mathrm{pH}, \mathrm{EC}, \mathrm{DO}$ and temperature. Measurements were made using an Orion Star A329 multi parameter water quality meter which was calibrated on a daily basis. Prior to each sample three well volumes were purged from the monitoring wells. During the experiment the wells were again purged and samples were collected following stabilisation of the field chemical characteristics. During the abstraction event on 22 April samples were collected every half hour over a ninety minute period.

Throughout this study we have used different terms for different types or states of organic carbon for clarity our interpretation of the terms is defined here; SOC - sedimentary or total amount of organic carbon in soil or sediment as measured by standard laboratory methods), DOC (portion of organic carbon [including chromophoric and fluorescent organic matter measured as FDOM] within water which passes through a $0.45 \mu \mathrm{m}$ filter.

Prior to its first use, a sample of the groundwater pump tubing was soaked in distilled water and a sample of the soak water was subjected to all analysis methods to ensure it would not be a source of DOC or fluorescent material. Water samples were field filtered using $0.45 \mu \mathrm{m}$ filters, collected in acid washed plastic containers and stored in an ice chest until analysis. Analysis for DOC was undertaken within five days of sampling by the UNSW Analytical Centre. The samples were acidified offline with $0.1 \mathrm{ml}$ of $\mathrm{H}_{3} \mathrm{PO}_{4}$ per $9.9 \mathrm{~mL}$ of sample and purged (using nitrogen) to eliminate the inorganic carbon interference. The treated samples were then measured for DOC by a TOC Analyser (Aurora 1030 wet oxidation TOC analyser, OI Analytical, College Station, TX, USA) as per method 5310D ${ }^{32}$.

Subsamples for fluorescence excitation/emission matrix (EEM) spectral analysis were also measured on the field filtered samples using an Horiba Aqualog Spectrofluorometer (ASF). Scans were conducted using excitation wavelengths from 240 to $400 \mathrm{~nm}$ at $10 \mathrm{~nm}$ steps. Emission wavelengths were collected from 210 to $600 \mathrm{~nm}$ at $2 \mathrm{~nm}$ bandwidth and $1 \mathrm{~s}$ integration time. The intensity of all EEM spectra was normalised by dividing the integrated intensity area of the Raman water curve at $350 \mathrm{~nm}$ wavelength excitation from the 370 to $450 \mathrm{~nm}$ emission wavelength range to give a quantitative fluorescence intensity $(\mathrm{QFI})^{53}$. Inner filter correction was undertaken and scatter lines masked.

The EEM data was then incorporated into an existing PARAFAC model which had been developed utilising 480 EEMs from the wider Wellington Research Station field site (Graham et al. 2015 ${ }^{36}$ ) using methodology described by Leurgans and Ross ${ }^{54}$, Bro $^{55}$ Stedmon and Bro ${ }^{56}$ and Chen, et al..$^{57}$. A three component model was derived by applying the PARAFAC method to the 480 EEMs. The three component model had a core consistency of 85 , a four component model was developed, however core consistency dropped significantly to 59 indicating an over-specified model $^{58}$. The three components were characterised by the following ranges: C1 - 300-350/400-450 nm Ex/Em and $<260 / 400-450 \mathrm{~nm} \mathrm{Ex} / \mathrm{Em}, \mathrm{C} 2-240-270 / 430-500 \mathrm{~nm}$ and 360-400/ 430-500 nm Ex/Em and C3 - 270-280/350 nm 
and $<250 / 350 \mathrm{~nm} \mathrm{Ex} / \mathrm{Em}$, corresponding to peaks M/C (terrestrial derived humic material), $\mathrm{C}^{+}$(reprocessed, allochthonous humic material) and $\mathrm{T}$ (tryptophan - microbial/protein like) respectively as described by Coble ${ }^{34}$ and Ishii and Boyer ${ }^{37}$. Absorbance data was also collected for a wavelength of $340 \mathrm{~nm}$ using the ASF.

Selected soil and sediment samples were collected directly from the drill cuttings during installation of the groundwater wells. These samples were placed directly into air tight plastic bags and were stored in a dark container until analysis. Selected samples were analysed by a National Association of Testing Authorities (NATA) accredited laboratory to determine TOC using the Walkley Black method ${ }^{33}$, a trimetric method that measures oxidisable organic content of soils on a one gram soil sample.

To determine the potential leachable quantity of OC within the site soil profile, Australian Standard Leaching Procedures (ASLPs (Australian Standard AS 4439.3 - 1997)) ${ }^{59}$ were used at a NATA accredited laboratory. The method was modified through use of three different leaching mediums (de-ionised water, 0.1 molar NaPyr and $0.5 \mathrm{molar} \mathrm{NaOH}$ ). The method utilised a $300 \mathrm{~g}$ mass of soil reduced to pass through a $2.4 \mathrm{~mm}$ aperture sieve and then evenly split between the three separate leaching mediums. The concentration of OC in the leachate was then determined using a TOC analyser applying the combustion method $5310 \mathrm{~B}$ as per Rice, et al. ${ }^{32}$.

\section{References}

1. Baker, A. \& Spencer, R. G. M. Characterization of dissolved organic matter from source to sea using fluorescence and absorbance spectroscopy. Sci Total Environ 333, 217-232, doi: 10.1016/j.scitotenv (2004).

2. Cory, R. M., McKnight, D. M., Chin, Y.-P., Miller, P. \& Jaros, C. L. Chemical characteristics of fulvic acids from Arctic surface waters: Microbial contributions and photochemical transformations. J Geophys Res-Biogeo 112, G04S51, doi: 10.1029/2006JG000343 (2007).

3. Jardine, P. M., McCarthy, J. F. \& Weber, N. L. Mechanisms of Dissolved Organic Carbon Adsorption on Soil. Soil Sci. Soc. Am. J. 53, 1378-1385, doi: 10.2136/sssaj1989.03615995005300050013x (1989).

4. Aiken, G. Organic Matter in Groundwater, Artificial Recharge Workshop Proceedings open file report 02-89 (ed US Geological Survey) 21-23 (2002)

5. Duan, S. \& Bianchi, T. S. Seasonal Changes in the Abundance and Composition of Plant Pigments in Particulate Organic Carbon in the Lower Mississippi and Pearl Rivers. Estuar Coast 29, 427-442, doi: 10.2307/3809762 (2006).

6. Duan, S., Bianchi, T. S. \& Sampere, T. P. Temporal variability in the composition and abundance of terrestrially-derived dissolved organic matter in the lower Mississippi and Pearl Rivers. Mar Chem 103, 172-184, doi: 10.1016/j.marchem.2006.07.003 (2007).

7. Benner, R. et al. Measurement of dissolved organic carbon and nitrogen in natural waters: Workshop report. Mar Chem 41, 5-10, doi: 10.1016/0304-4203(93)90101-S (1993).

8. Blazejewski, G. A., Stolt, M. H., Gold, A. J., Gurwick, N. \& Groffman, P. M. Spatial Distribution of Carbon in the Subsurface of Riparian Zones. Soil. Sci. Soc. Am. J 73, 1733-1740, doi: 10.1029/2007jg000482 (2009).

9. Peter, S., Shen, Y., Kaiser, K., Benner, R. \& Durisch-Kaiser, E. Bioavailability and diagenetic state of dissolved organic matter in riparian groundwater. J Geophys Res-Biogeo 117, doi: 10.1029/2012JG002072 (2012).

10. Leenheer, J. A. In Artificial Recharge Workshop Proceedings. (ed G. R. Aiken, Kuniansky, E. L.,) 24-26 (US Geological Survey).

11. Seifert, D. \& Engesgaard, P. Use of tracer tests to investigate changes in flow and transport properties due to bioclogging of porous media. J Contam Hydrol 93, 58-71, doi: 10.1016/j.jconhyd.2007.01.014 (2007).

12. Tang, Y., Valocchi, A. J. \& Werth, C. J. A hybrid pore-scale and continuum-scale model for solute diffusion, reaction, and biofilm development in porous media. Water Resour Res 51, 1846-1859, doi: 10.1002/2014WR016322 (2015).

13. Tang, Y., Valocchi, A. J., Werth, C. J. \& Liu, H. An improved pore-scale biofilm model and comparison with a microfluidic flow cell experiment. Wat Resour Res 49, 8370-8382, doi: 10.1002/2013WR013843 (2013).

14. Thullner, M. Comparison of bioclogging effects in saturated porous media within one- and two-dimensional flow systems. Ecol Eng 36, 176-196, doi: 10.1016/j.ecoleng.2008.12.037 (2010).

15. Thullner, M., Mauclaire, L., Schroth, M. H., Kinzelbach, W. \& Zeyer, J. Interaction between water flow and spatial distribution of microbial growth in a two-dimensional flow field in saturated porous media. J Contam Hydrol 58, 169-189, doi: 10.1016/S01697722(02)00033-5 (2002).

16. Thullner, M., Schroth, M. H., Zeyer, J. \& Kinzelbach, W. Modeling of a microbial growth experiment with bioclogging in a twodimensional saturated porous media flow field. J Contam Hydrol 70, 37-62, doi: 10.1016/j.jconhyd.2003.08.008 (2004).

17. MacDonald, T. R., Kitanidis, P. K., McCarty, P. L., Roberts, P. V. \& Effects of shear detachment on biomass growth and in situ bioremediation. Groundwater 37, 555-563, doi: 10.1111/j.1745-6584.1999.tb01142.x (1999).

18. Pintelon, T. R. R., Graf von der Schulenburg, D. A. \& Johns, M. L. Towards optimum permeability reduction in porous media using biofilm growth simulations. Biotechnol Bioeng 103, 767-779, doi: 10.1002/bit.22303 (2009).

19. Pintelon, T. R. R., Picioreanu, C., van Loosdrecht, M. C. M. \& Johns, M. L. The effect of biofilm permeability on bio-clogging of porous media. Biotechnol Bioeng 109, 1031-1042, doi: 10.1002/bit.24381 (2012).

20. Ross, N., Novakowski, K. S., Lesage, S., Deschênes, L. \& Samson, R. Development and resistance of a biofilm in a planar fracture during biostimulation, starvation, and varying flow conditions. J Environ Eng Sci 6, 377-388, doi: 10.1139/s06-056 (2007).

21. McKinley, V. L., Costerton, J. W. \& White, D. C. Microbial Biomass, Activity, and Community Structure of Water and Particulates Retrieved by Backflow from a Waterflood Injection Well. Appl Environ Microb 54, 1383-1393 (1988).

22. Ebigbo, A., Helmig, R., Cunningham, A. B., Class, H. \& Gerlach, R. Modelling biofilm growth in the presence of carbon dioxide and water flow in the subsurface. Adv Water Resour 33, 762-781, doi: 10.1016/j.advwatres.2010.04.004 (2010).

23. Brovelli, A., Malaguerra, F. \& Barry, D. A. Bioclogging in porous media: Model development and sensitivity to initial conditions. Environ Modell Softw 24, 611-626, doi: 10.1016/j.envsoft.2008.10.001 (2009).

24. Tufenkji, N. Modeling microbial transport in porous media: Traditional approaches and recent developments. Adv Water Resour 30, 1455-1469, doi: 10.1016/j.advwatres.2006.05.014 (2007).

25. Lawson, M. et al. Pond-Derived Organic Carbon Driving Changes in Arsenic Hazard Found in Asian Groundwaters. Environ Sci Technol 47, 7085-7094, doi: 10.1021/es400114q (2013).

26. Mailloux, B. J. et al. Advection of surface-derived organic carbon fuels microbial reduction in Bangladesh groundwater. $P$ Natl Acad Sci 110, 5331-5335, doi: 10.1073/pnas.1213141110(2013).

27. Cloete, T. E., Westaard, D. \& van Vuuren, S. J. Dynamic response of biofilm to pipe surface and fluid velocity. Water Sci Technol 47, 57-59 (2003)

28. Choi, Y. C. \& Morgenroth, E. Monitoring biofilm detachment under dynamic changes in shear stress using laser-based particle size analysis and mass fractionation. Water Sci Technol 47, 69-76 (2003)

29. Knutson, C. E., Werth, C. J. \& Valocchi, A. J. Pore-scale simulation of biomass growth along the transverse mixing zone of a model two-dimensional porous medium. Water Resour Res 41, doi: 10.1029/2004WR003459 (2005).

30. Rittmann, B. E. The significance of biofilms in porous media. Water Resour Res 29, 2195-2202, doi: 10.1029/93WR00611 (1993).

31. Rittmann, B. E. The effect of shear stress on biofilm loss rate. Biotechnol Bioeng 24, 501-506, doi: 10.1002/bit.260240219 (1982).

32. Rice, E. W., Baird, R. B., Eaton, A. D. \& Clesceri, L. S. Standard Methods for the Examination of Water and Wastewater 22nd Edition. (American Public Health Association, 2012) 
33. Lyons, G. E. \& David, J. Soil Chemical Methods-Australasia. (CSIRO Publishing, 2010).

34. Coble, P. G. Characterization of marine and terrestrial DOM in seawater using excitation-emission matrix spectroscopy. Mar Chem 51, 325-346, doi: 10.1016/0304-4203(95)00062-3 (1996).

35. Wolfbeis, O. S. Fluorescence Spectroscopy, New Methods and Applications. (Springer-Verlag, 2012).

36. Graham, P. W., Baker, A., Andersen, M. S. \& Acworth, I. Field Measurement of Fluorescent Dissolved Organic Material as a Means of Early Detection of Leachate Plumes. Water Air Soil Poll 226, 1-18, doi: 10.1007/s11270-015-2475-6 (2015).

37. Ishii, S. K. L. \& Boyer, T. H. Behavior of Reoccurring PARAFAC Components in Fluorescent Dissolved Organic Matter in Natural and Engineered Systems: A Critical Review. Environ Sci Technol 46, 2006-2017, doi: 10.1021/es2043504 (2012).

38. Stewart, A. J. \& Wetzel, R. G. Fluorescence: Absorbance Ratios-a Molecular-Weight Tracer of Dissolved Organic Matter. Limnol Oceanogr 25, 559-564, doi: 10.2307/2835308 (1980).

39. Belzile, C. \& Guo, L. Optical properties of low molecular weight and colloidal organic matter: Application of the ultrafiltration permeation model to DOM absorption and fluorescence. Mar Chem 98, 183-196, doi: 10.1016/j.marchem.2005.08.009 (2006).

40. Baker, A., Tipping, E., Thacker, S. A. \& Gondar, D. Relating dissolved organic matter fluorescence and functional properties. Chemosphere 73, 1765-1772, doi: 10.1016/j.chemosphere.2008.09.018 (2008).

41. Moore, T. R. \& Dalva, M. Some controls on the release of dissolved organic carbon by plant tissues and soils. Soil Sci 166, 38-47 (2001).

42. Borisover, M., Lordian, A. \& Levy, G. J. Water-extractable soil organic matter characterization by chromophoric indicators: Effects of soil type and irrigation water quality. Geoderma 179-180, 28-37, doi: 10.1016/j.geoderma.2012.02.019 (2012).

43. Wang, C. et al. The effect of flow velocity on the distribution and composition of extracellular polymeric substances in biofilms and the detachment mechanism of biofilms. Water Sci Technol 69, 825-832 (2014).

44. Baveye, P., Vandevivere, P., Hoyle, B. L., DeLeo, P. C. \& de Lozada, D. S. Environmental Impact and Mechanisms of the Biological Clogging of Saturated Soils and Aquifer Materials. Cr Rev Environ Sci Technol 28, 123-191, doi: 10.1080/10643389891254197 (1998).

45. Ochoa, J.-C., Coufort, C., Escudié, R., Liné, A. \& Paul, E. Influence of non-uniform distribution of shear stress on aerobic biofilms. Chem Eng Sci 62, 3672-3684, doi: 10.1016/j.ces.2007.03.023 (2007).

46. Rochex, A., Godon, J.-J., Bernet, N. \& Escudié, R. Role of shear stress on composition, diversity and dynamics of biofilm bacterial communities. Water Res 42, 4915-4922, doi: 10.1016/j.watres.2008.09.015 (2008).

47. Quinn, P. M., Parker, B. L. \& Cherry, J. A. Using constant head step tests to determine hydraulic apertures in fractured rock. J Contam Hydrol 126, 85-99, doi: 10.1016/j.jconhyd.2011.07.002 (2011).

48. Driscoll, F. G. Groundwater and Wells. (Johnson Filtration Division, 1986).

49. Novakowski, K., Bickerton, G., Lapcevic, P., Voralek, J. \& Ross, N. Measurements of groundwater velocity in discrete rock fractures. J Contam Hydrol 82, 44-60, doi: 10.1016/j.jconhyd.2005.09.001 (2006).

50. Robinson, N. I., Sharp Jr, J. M. \& Kreisel, I. Contaminant transport in sets of parallel finite fractures with fracture skins. J Contam Hydrol 31, 83-109, doi: 10.1016/S0169-7722(97)00055-7 (1998).

51. Nair, V. V. \& Thampi, S. G. Numerical modelling of colloid transport in sets of parallel fractures with fracture skin. Colloid Surface A 364, 109-115, doi: 10.1016/j.colsurfa.2010.05.003 (2010).

52. van Beek, C. G. E. M. et al. Concentration and size distribution of particles in abstracted groundwater. Water Res 44, 868-878 (2010).

53. Lawaetz, A. J. \& Stedmon, C. A. Fluorescence Intensity Calibration Using the Raman Scatter Peak of Water. Appl. Spectrosc. 63, 936-940 (2009).

54. Leurgans, S. \& Ross, R. T. Multilinear Models: Applications in Spectroscopy. Stat Sci 7, 289-310, doi: 10.2307/2246065 (1992).

55. Bro, R. PARAFAC. Tutorial and applications. Chemometr Intell Lab 38, 149-171, doi: 10.1016/S0169-7439(97)00032-4 (1997)

56. Stedmon, C. A. \& Bro, R. Characterizing dissolved organic matter fluorescence with parallel factor analysis: a tutorial. Limnol and Oceanogr 6, 572-579, doi: 10.4319/lom.2008.6.572 (2008).

57. Chen, M., Price, R. M., Yamashita, Y. \& Jaffé, R. Comparative study of dissolved organic matter from groundwater and surface water in the Florida coastal Everglades using multi-dimensional spectrofluorometry combined with multivariate statistics. Appl Geochem 25, 872-880 (2010).

58. Coble, P. G., Lead, J., Baker, A., Reynolds, D. M. \& Spencer, R. G. Aquatic Organic Matter Fluorescence. (Cambridge University Press, 2014).

59. AS4439.3-1997. in Wastes, Sediments and Contaminated Soils, Part 3: Preparation of leachates-Bottle leaching procedure AS 4439.3 - 1997 (Standards Australia, 1997).

\section{Acknowledgements}

P.G. was funded by a grant from NSW-SLF. Bores utilised were installed utilising funding from the Federal Government NCRIS Groundwater Infrastructure program. Analysis of SOC samples was funded by the National Groundwater Research and Training Centre.

\section{Author Contributions}

The experiment was conceived and undertaken by P.G. and A.B. P.G. analysed the results, P.G., A.B. and M.A. reviewed the manuscript.

\section{Additional Information}

Supplementary information accompanies this paper at http://www.nature.com/srep

Competing financial interests: The authors declare no competing financial interests.

How to cite this article: Graham, P. W. et al. Dissolved Organic Carbon Mobilisation in a Groundwater System Stressed by Pumping. Sci. Rep. 5, 18487; doi: 10.1038/srep18487 (2015).

This work is licensed under a Creative Commons Attribution 4.0 International License. The images or other third party material in this article are included in the article's Creative Commons license, unless indicated otherwise in the credit line; if the material is not included under the Creative Commons license, users will need to obtain permission from the license holder to reproduce the material. To view a copy of this license, visit http://creativecommons.org/licenses/by/4.0/ 